\title{
The comparison of modified semilunar technique in conjunction with connective tissue and subepithelial connective tissue graft for root coverage: a randomized controlled trial
}

\author{
Niloofar Jenabian ${ }^{1}$, Nafiseh Khanjani ${ }^{2}$, Ali Bijani ${ }^{3}$
}

${ }^{1}$ Specialist in Periodontology, Associate Professor, Department of Periodontology, Faculty of Dentistry, Babol University of Medical Science, Babol, Iran

${ }^{2}$ Postgraduate Student in Periodontology, Department of Periodontology, Faculty of Dentistry, Babol University of Medical Science, Babol, Iran

${ }^{3}$ M.D., Social Determinants of Health Research Center, Health Research Institute, Babol University of Medical Science, Babol, Iran

\section{Type of article: Original}

\begin{abstract}
Background: Gingival recession may result in aesthetically unfavourable effects, difficulty in plaque control, increased susceptibility to root caries, and dentin hypersensitivity.

Objective: The aim of this study was to compare the use of modified semilunar techniques with connective tissue and subepithelial connective tissue grafts (Langer) for denuded root surface coverage.

Methods: In this randomized clinical trial, fourteen localized recessions of Miller class I to II were treated in 5 subjects. Recessions were randomly treated with modified semilunar techniques (test group) and a subepithelial connective tissue graft (control group). Clinical parameters such as clinical attachment level (CAL), keratinized tissue width (KTW), probing pocket depth (PPD), vertical recession depth (VRD) and recession width (RW)were recorded at base line, 1, 3 and 6 months after surgery and healing index and the subject's satisfaction was evaluated. The repeated measure test and paired-sample t-test were used for statistical analyses by SPSS.

Results: Both methods showed significant improvement in clinical parameters. The healing index (HI) in the test group was a slightly more than the control group in Day 10.Aesthetic VAS (Visual Analogue Scale) levels in the test group were more than the control group in 1,3 and 6months (test group, in 1 month $6.57 \pm 1.13$, in 3 month $7.86 \pm 1.07$, in 6 month $8.00 \pm 0.81$. control group in 1 month $5.57 \pm 1.13$, in 3 month $7.00 \pm 1.00$, in 6 month $7.14 \pm 0.90)$. The KTW, CAL, VRD and RW level's difference in the test and control group was significant in 6 month compared to the base line $(\mathrm{p}=0.000)$.

Conclusions: The present study shows that treatment of Miller Class I and II gingival recession by the modified semilunar technique is acceptable.

Clinical trial registration: The trial was registered at the Iranian Registry of Clinical Trials (http://www.irct.ir) with the Irct ID: IRCT201512021760N43. Date registered: December 27, 2015.

Funding: The authors received no financial support for the research, authorship, and/or publication of this article.

Keywords: Gingival recession, Autografting, Connective tissue, Subepithelial connective tissue graft
\end{abstract}

\section{Introduction}

Gingival recession has been described as the apical displacement of the gingival margin in relation to the cementoenamel junction (CEJ)) 1). Histologically, the collapse of gingival tissue results in attachment loss by destruction of the periodontal connective tissue and alveolar bone (2). The etiologic factors for gingival marginal recession are inflammatory periodontal disease (3), mechanical trauma (4), tooth malposition, root prominence, aberrant frenal attachment (5), orthodontic tooth movement (6,7), underlying alveolar dehiscence(7,8), gingival phenotype(9), and iatrogenic restorative and periodontal treatment-related factors (10).It may result in aesthetically unfavourable

\section{Corresponding author:}

Dr. Nafiseh Khanjani, Department of Periodontology, Faculty of Dentistry, Babol University of Medical Science, Babol, Iran. Tel: +98.1132199592, Fax:+98.1132190181, Email: khanjani_n65@yahoo.com

Received: April 27, 2016, Accepted: August 21, 2016, Published: February 2017

iThenticate screening: June 30, 2016, English editing: September 20, 2016, Quality control: December 21, 2016

(C) 2017 The Authors. This is an open access article under the terms of the Creative Commons Attribution-NonCommercialNoDerivs License, which permits use and distribution in any medium, provided the original work is properly cited, the use is non-commercial and no modifications or adaptations are made. 
effects (11), difficulty in plaque control, increased susceptibility to root caries (12), and dentin hypersensitivity (13). Millers Classes I and II gingival marginal recession shows $100 \%$ success rate to root coverage procedures, Class III shows 50 to $70 \%$ success, and Class IV shows only 0 to $10 \%$ success (14). The different root coverage procedures are free gingival autograft (15-19), free connective tissue autograft (15-18), pedicle autograft (19-25) such as a laterally positioned flap and coronally positioned flap - semilunar pedicle (Tarnow), subepithelial connective tissue graft (Langer), guided tissue regeneration (GTR), and the Pouch and Tunnel technique. The different pedicle grafts are rotational flaps like the laterally positioned, double papilla, and transpositional flap, and advanced flaps like coronally advanced flap and semilunar flap (15-21). Subepithelial connective tissue grafting presents a high degree of predictability when used to treat Miller's classes I and II gingival recession (25). One of the advantages of Langer technique is that healing is primarily done, and the discomfort after surgery caused by the wound of the donor area is less, because the graft is prepared only from the underside of the palatal flap and the palatal flap is sutured in its original location. On the other hand, it is aesthetically compared to the free gingival graft (FGG) technique. Because the colour matching of the transplanted tissue is better with the surrounding areas (26).Semilunar technique is the modification of the coronally displaced flap. As a result, the blood supply to the tissue covering the root will not be at risk. Tissue graft may change appearance and colour but it is not observed and other benefits include simultaneously applying for multiple adjacent teeth and the subject's comfort. Pandit et al. presented a new report on a new technique for covering multiple recession defects in which the semilunar vestibular incision technique had been used (27).The aim of this study was to try to compare the modified semilunar technique with the standard subepithelial Connective Tissue Graft Technique, for root coverage in Miller classes I and II recession defects, in terms of esthetic and post-surgical pain intensity.

\section{Material and Methods}

\subsection{Trial design and sample size}

This study was a randomized controlled clinical trial. The subject was selected from the patient who was referred to the Department of Periodontology at Babol University of Medical Science. According to previous studies, at least 10 sites were selected as the sample size for this study (27).

\subsection{Selection criteria}

Five subjects with 14 sites of gingival recessions were selected. Subject' $s$ inclusion criteria were as follows: 1) The existence of single unilateral/bilateral gingival recession defects with a CEJ depth of $\mathrm{X} \leq 2 \mathrm{~mm}$ in anterior or premolars teeth, 2) All recessions must be in Miller classes I/II subgroup, 3) The selected teeth must be without Root restoration and/or bleeding on probing, 4) People must be aged 18 or older, 5) Ability to maintain good oral hygiene (O'Leary plaque score $\leq 20 \%$ ), and 6) Sufficient vestibular depth. Exclusion criteria were: 1) smoking; 2) pregnancy; 3 ) root surface restorations; 4 ) endodontic treatment; and 5) poor oral hygiene ( $\mathrm{O}^{\prime}$ leary plaque score $>20 \%$ ).

\subsection{Outcomes}

At base line, 1, 3 and 6 months after the surgical procedures the following clinical parameters were measured to 0.5 millimeter accuracy with a University of Michigan "O" probe with Williams marking:

1) Keratinized tissue width $(K T W)$ : distance between the most apical part of gingival margin and mucogingival junction (MGJ)

2) Clinical attachment level (CAL): distance between Cemento-enamel junction (CEJ) and bottom of the pocket

3) Probing pocket depth (PPD): distance between the most apical part of gingival margin and bottom of the pocket at three points; mesial, midbuccal and distal

4) Vertical recession depth (VRD): distance between CEJ and the most apical part of gingival margin

5) Recession width $(R W)$ : width of exposed root at the level of $1 \mathrm{~mm}$ apical to CEJ

On the 10th day (suture removal session), the subjects were asked about postsurgical pain using a visual analogue scale (VAS) with 10 points which 0 indicated no pain and 10 indicated the worst pain they may have ever experienced. In addition, subjects were questioned for esthetic at 1,3 and 6 months after surgery. Subject satisfaction was assessed using a 10 points scale (VAS) of which0 was unsatisfactory and 10 was fully satisfactory. Landry healing index (HI) was assessed on the10th day and 1 month after surgery (28).

\subsection{Intervention}

Scaling and root-planning was performed on all subjects participating in the study, and all subjects received oral hygiene instruction. Occlusal Adjustment was performed if needed. Bilateral recessions on the buccal aspects of maxillary premolars and incisors were selected. Sites of surgery were randomly selected. In subjects with bilateral 
recession defects, areas of surgery were randomly divided into two sections per person of which one side was treated with modified semilunar technique with the connective tissue (test group)and the other side with the sub epithelial Connective Tissue Graft Technique (control group). All procedures were performed by one practitioner and the randomized and clinical measurements of making cases were done by the examiner. After adequate anesthesia with lidocaine, (2\%) with epinephrine 1:80,000 using the infiltration technique, root planning of the exposed surfaces were performed in each group. In the control group, preparation of the recipient area was done by a sulcular incision adjacent to the interdental papilla, and partial thickness flap was extended beyond the MGJ. The mesiodistal length of the incision continues to the distal line angle of the nearest distal teeth and the mesial line angle of the nearest mesial tooth. Width required for connective tissue graft was obtained by using a periodontal probe. Connective tissue graft thickness was about 1-1.5 mm which was harvested from the palate area and stabilized using absorbable polyglycolic acid sutures $(0-4)$ and sling technique. Then the flap was coronally moved to cover the graft completely and was stabilized using silk (0-4) suture in sling technique. The donor areas were sutured with silk $0-4$, and both recipient and donor areas were covered with the non-eugenol periodontal dressing. In the modified semilunar technique, a 1-2 millimeter semilunar incision was created in parallel with the curvature of the gingival margin of the denuded root. To maintain the blood supply of the flap, the end of the incision on both sides was two to three millimeters shorter than the papilla tip. Then the split-thickness flap was slightly removed from the underlying connective tissue using Dask set Pens and was coronally placed, then the connective tissue parts that had been harvested from the palate were placed in the papilla area and denuded root surface for accurately establishing the flap (similar to the previous method) (Figure 1). Finally, the recipient area was subject to pressure for a few minutes and was placed in the appropriate site with minimal suture. The sutures were removed after 10.Subjects were advised not to brush their teeth at the surgical site, avoid chewing hard things and rinse with $0.2 \%$ solution of chlorhexidine digluconate daily for 3 weeks. Systemic antibiotics (Amoxicillin 500mg, tid) were prescribed for 1 week. After 10 days, the subjects were instructed to resume gentle brushing directed coronally in the operated sites. Postsurgical recalls were scheduled every other week during the first month and 1, 3 and 6 months after surgery (Figure 2).

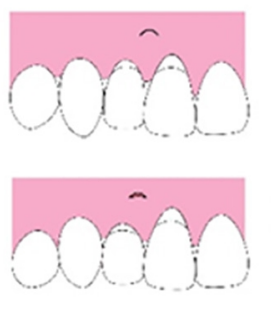

\section{A. Modified semilunar incision}

\section{B. Partial thickness coronally advanced flap}

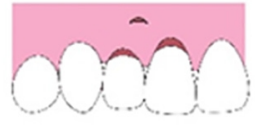

\section{Placement of connective tissue graft}

Figure 1. Schematic diagram of modified semilunar technique

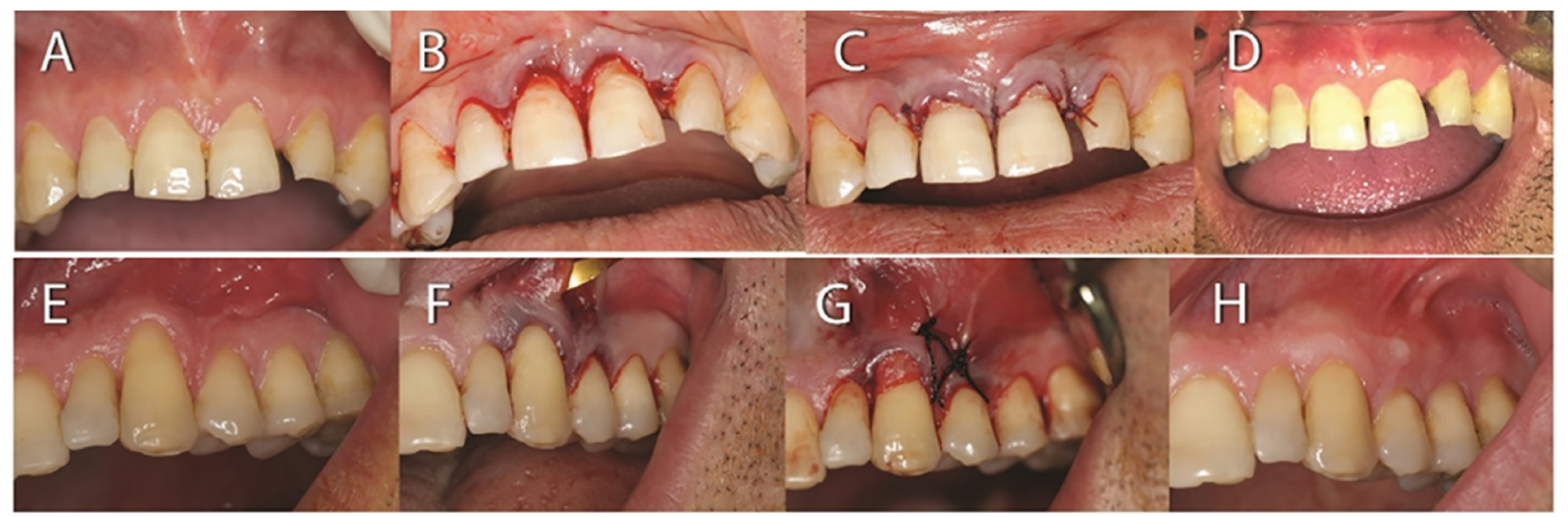

Figure 2. Surgical procedure and follow-up in Langer technique: A. Initial clinical appearance, B. recipient site preparation, C. suturing, D. after 6 months surgical procedure and follow-up in modified semilunar technique: E. Initial clinical appearance, F. recipient site preparation, G. suturing, H. after 6 months 


\subsection{Research ethics}

The proposal for this thesis research was presented to the Ethics Committee at Babol University of Medical Science. The Ethics Committee approved the study with the number P/J/305262 on March 14, 2015.All details of study and alternative treatments were explained to participants and were signed in informed consent. Sites of surgery were randomly selected.

\subsection{Statistical analyses}

Statistical analyses were performed using IBM(C SPSSC Statistics version 21 (IBM@ Corp., Armonk, NY, USA). Quantitative data of the recession sites were recorded as mean \pm SD of midbuccal measurements. Statistical analyses used were the repeated measure test for intragroup comparisons and the paired t-test for intergroup comparisons.

\section{Results}

All subjects participating in this study completed follow-up sessions and healing occurred in these subjects without any problems. Figure 3 shows the CONSORT flow diagram of the trial. Statistically significant differences were not found between the two groups in the presurgical parameters (Table 1). The width of the keratinized gingiva in Months 1 and 6 were slightly higher in the test group (Month 1 test group, $7.07 \pm 1.88$, control group 6.86 \pm 1.57 , and Month 6 of the test group $7.14 \pm 1.35$ vs. control group $6.64 \pm 1.18$ ) but this difference were not significant The CAL level at baseline time in the test group is $3.21 \pm 0.80$ and in control group was $2.71 \pm 0.57$ and both of them were equal at Month 6, but CAL was more decreased in the test group. The measured pain on a scale of 0-10 was about the same in both groups (test group $2.71 \pm 1.70$, control group: $2.86 \pm 0.70$ ). HI in the test group was a slightly more than the control group in Day 10, but this amount was identical in the two groups in the first month. Aesthetic VAS level was more than the control group in 1-month, 3-month and 6-month measurements in the test group (test group, in 1 month $6.57 \pm 1.13$, in 3 month $7.86 \pm 1.07$, in 6 month $8.00 \pm 0.81$. control group in 1 month $5.57 \pm 1.13$, in 3 month $7.00 \pm 1.00$, in 6 month 7.14 \pm 0.90 ). The KTW, CAL, VRD and RW level's difference in the test and control group were significant in the sixth month compared to the base line (Table 2, 3). RC percentages in the control group and the test group were not significant ( $\mathrm{p}$-value in control 0.335 , in test 0.457 ).

Subjects visited with gingival recession complaint ( $n=5$ or 14 sites)

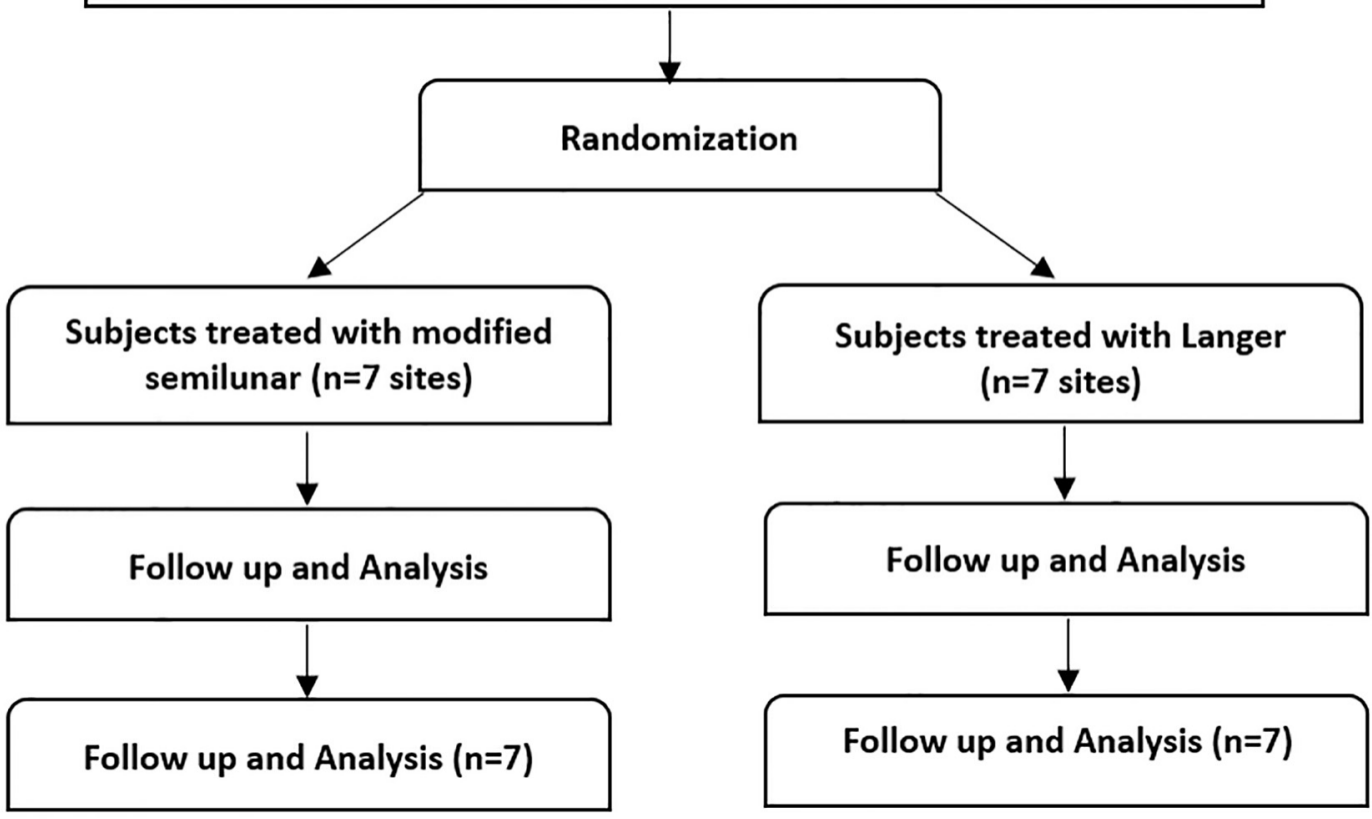

Figure 3. CONSORT flow diagram of the trial 
Table1. Base line characteristics

\begin{tabular}{|l|l|l|l|}
\hline Initial data & Langer $($ Mean \pm SD) & Modified semilunar $($ Mean \pm SD) & p-value \\
\hline KTW $(\mathrm{mm})$ & $4.43 \pm 1.13$ & $5.00 \pm 1.73$ & 0.512 \\
\hline CAL $(\mathrm{mm})$ & $2.71 \pm 0.57$ & $3.21 \pm 0.80$ & 0.287 \\
\hline PPD $(\mathrm{mm})$ & $0.93 \pm 0.19$ & $1.14 \pm 0.63$ & 0.708 \\
\hline VRD $(\mathrm{mm})$ & $1.71 \pm 0.49$ & $2.21 \pm 0.39$ & 0.054 \\
\hline RW $(\mathrm{mm})$ & $2.36 \pm 1.03$ & $3.00 \pm 0.96$ & 0.239 \\
\hline
\end{tabular}

Table 2. Measurement of clinical parameters at base line, $1^{\text {st }}, 3^{\text {rd }}$ and $6^{\text {th }}$ months (modified semilunar)

\begin{tabular}{|l|l|l|l|l|l|}
\hline Parameters & $\begin{array}{l}\text { Baseline }(\text { Mean } \pm \\
\text { SD) }\end{array}$ & $\begin{array}{l}1^{\text {st }} \text { month (Mean } \pm \\
\text { SD) }\end{array}$ & $\begin{array}{l}3^{\text {rd }} \\
\text { SD) }\end{array}$ & $\begin{array}{l}6^{\text {th }} \text { month }(\text { Mean } \pm \\
\text { SD) }\end{array}$ & $\begin{array}{l}\text { p- } \\
\text { value }\end{array}$ \\
\hline $\begin{array}{l}\text { KTW } \\
(\mathrm{mm})\end{array}$ & $5.00 \pm 1.73$ & $7.07 \pm 1.28$ & $6.71 \pm 1.80$ & $7.14 \pm 1.35$ & 0.000 \\
\hline CAL $(\mathrm{mm})$ & $3.21 \pm 0.80$ & $1.71 \pm 0.64$ & $1.43 \pm 0.45$ & $1.57 \pm 0.53$ & 0.000 \\
\hline PPD $(\mathrm{mm})$ & $1.14 \pm 0.63$ & $0.71 \pm 0.27$ & $0.86 \pm 0.24$ & $0.78 \pm 0.27$ & 0.230 \\
\hline VRD $(\mathrm{mm})$ & $2.21 \pm 0.39$ & $0.86 \pm 0.56$ & $0.78 \pm 0.39$ & $1.00 \pm 0.50$ & 0.000 \\
\hline RW $(\mathrm{mm})$ & $3.00 \pm 0.96$ & $1.07 \pm 0.93$ & $0.64 \pm 0.94$ & $0.86 \pm 0.75$ & 0.000 \\
\hline
\end{tabular}

Table 3. Measurement of clinical parameters at base line, $1^{\text {st }}, 3^{\text {rd }}$ and $6^{\text {th }}$ months (Langer)

\begin{tabular}{|l|l|l|l|l|l|}
\hline Parameters & $\begin{array}{l}\text { Baseline }(\text { Mean } \pm \\
\text { SD) }\end{array}$ & $\begin{array}{l}1^{\text {st }} \text { month (Mean } \pm \\
\text { SD) }\end{array}$ & $\begin{array}{l}3^{\text {rd }} \\
\text { SD) }\end{array}$ & $\begin{array}{l}6^{\text {th }} \text { month }(\text { Mean } \pm \\
\text { SD) }\end{array}$ & $\begin{array}{l}\text { p- } \\
\text { value }\end{array}$ \\
\hline $\begin{array}{l}\text { KTW } \\
(\mathrm{mm})\end{array}$ & $4.43 \pm 1.13$ & $6.86 \pm 1.57$ & $6.71 \pm 1.25$ & $6.64 \pm 1.18$ & 0.000 \\
\hline CAL $(\mathrm{mm})$ & $2.71 \pm 0.57$ & $1.50 \pm 0.41$ & $1.36 \pm 0.38$ & $1.57 \pm 0.45$ & 0.000 \\
\hline PPD $(\mathrm{mm})$ & $0.93 \pm 0.19$ & $1.07 \pm 0.35$ & $1.00 \pm 0.41$ & $1.21 \pm 0.49$ & 0.415 \\
\hline VRD $(\mathrm{mm})$ & $1.71 \pm 0.49$ & $0.28 \pm 0.39$ & $0.50 \pm 0.71$ & $0.43 \pm 0.73$ & 0.000 \\
\hline RW $(\mathrm{mm})$ & $2.36 \pm 1.03$ & $0.43 \pm 1.13$ & $0.21 \pm 0.57$ & $0.28 \pm 0.75$ & 0.000 \\
\hline
\end{tabular}

\section{Discussion}

In this clinical trial, subjects with Miller classes I and II Gingival recession were treated by two methods; modified semilunar technique and subepithelial connective tissue graft, the clinical evaluations were conducted for 6 months. According to the results obtained by this study, benefits of modified semilunar techniques are as follows: Less (or equal) pain after surgery than the control group, a higher degree of healing index on the tenth day, more subject' satisfaction of the aesthetics in the first, third and sixth months, a further reduction in CAL in the sixth month and more width of the attached gingiva in the first and sixth months. These results are indicative of improved periodontal parameters by this modification of root coverage surgery. Differences in KTW, CAL, VRD and RW at 1, 3, 6 months rather than base line, were statistically significant in both groups. The differences between the two groups were not statistically significant, which is probably due to a small sample size. In future studies, it is recommended to select test and control groups with larger sample sizes to solve this problem The criteria for successful root coverage are as follows: The gingival margin is on CEJ in Class I, Class II gingival marginal recession, the depth of gingival sulcus is within $2 \mathrm{~mm}$, there is no bleeding on probing, there is no hypersensitivity, and colour match with adjacent tissue is aesthetically harmonious (14).All subjects participating in this study had appropriate criteria for the successful root coverage and all subjects declared minimal discomfort after surgery - both in the recipient and the donor area. This technique is a kind of coronally displaced flap and consequently the blood-supply to the tissue covering the root will not be at risk. Changing the colour of the transplanted tissue is not observed and its other benefits include simultaneously applying for multiple adjacent teeth, lack of need for sutures as what can be seen in the connective tissue graft technique and comfort for the subject. In the modified semilunar technique presented in this study, there is the possibility of simultaneous surgery for several dental surgeries with the least amount of incision - and fewer sutures are needed compared with connective tissue graft. There is also less discomfort for subjects. In a case series study, Pai et al. investigated the modified semilunar coronally advanced flap procedure which was introduced by Kamran Haqiqat (29) in 2006 (30). Some of its benefits are better control of flap displacement as well as apical tissues tension reduction during root coverage of adjacent teeth (29). This technique requires sufficient thickness and width of keratinized tissue in the apical defect (29). In the modified semilunar technique which has been introduced in this study, as the width of keratinized gingiva significantly increases after surgery, the width of the keratinized gingiva is not required before the surgery and, in addition, the short incision 
line that is a special feature of modified semilunar technique leads to lower pain and postsurgical discomfort in subjects rather than the modified semilunar coronally advanced flap. Minimum number of sutures, short incision line, improvement of periodontal parameters and the satisfaction of most subjects are the advantages of the modified semilunar technique. This study had some limitations. The lesser number of subjects with inclusion criteria and no regular follow up sessions were limitations of this study.

\section{Conclusions}

Comparing the two techniques that were examined in this study, there was no significant difference in the root coverage treatment, statistically. The present study shows that treatment of Miller Classes I and II gingival recession by the modified semilunar technique is acceptable. This technique has benefits compared to the Langer technique such as less pain, more comfort and the minimal use of sutures. More studies are needed with longer follow-up time. It is recommended that future studies with more sample size are designed.

\section{Clinical trial registration:}

The trial was registered at the Iranian Registry of Clinical Trials (http:/www.irct.ir) with the Irct ID: IRCT201512021760N43. Date registered: December 27, 2015.

\section{Funding:}

The authors received no financial support for the research, authorship, and/or publication of this article

\section{Acknowledgments:}

This paper was extracted from Dr. Nafiseh Khanjani periodontology residency thesis at Babol University of Medical Sciences, Babol, Iran. The authors thank Dr. Mohadeseh Yazdanpanah, staffs of Babol Department of Periodontology and Research and Technology committee of Babol University of Medical Science for their help and participation in this study.

\section{Conflict of Interest:}

There is no conflict of interest to be declared.

\section{Authors' contributions:}

All authors contributed to this project and article equally. All authors read and approved the final manuscript.

\section{References:}

1) American Academy of Periodontology. Glossary of periodontal terms. 4th ed, American Academy of Periodontology, Chicago, 44. 2001.

2) Henriques PS, Pelegrine AA, Nogueira AA, Borghi MM. Application of subepithelial connective tissue graft with or without enamel matrix derivative for root coverage: a split-mouth randomized study. J Oral Sci. 2010; 52(3): 463-71. doi: 10.2334/josnusd.52.463. PMID: 20881341.

3) Loe H, Anerud A, Boysen H. The natural history of periodontal disease in man: Prevalence, severity and extent of gingival recession. J Periodontol. 1992; 63(6): 489-95. doi: 10.1902/jop.1992.63.6.489. PMID: 1625148.

4) Edwards JG. The diastema, the frenum, the frenectemy: A clinical study. Am J Orthod. 1977; 71(5): 489508. doi: 10.1016/0002-9416(77)90001-X. PMID: 266363.

5) Coatoam GW, Behrents RG, Bissada NF. The width of keratinized gingiva during orthodontic treatment: Its significance and impact on periodontal status. J Periodontol. 1981; 52(6): 307-13. doi: 10.1902/jop.1981.52.6.307. PMID: 6167704.

6) Boyd RL. Mucogingival considerations and their relationship to orthodontics. J Periodontol. 1978; 49(2): 67-76. doi: 10.1902/jop.1978.49.2.67. PMID: 276594.

7) Lost C. Depth of alveolar dehiscences in relation to gingival recessions. J Clin Periodontol. 1984; 11(9): 583-9. doi: 10.1111/j.1600-051X.1984.tb00911.x. PMID: 6593330.

8) Muller HP, Eqer T. Gingival phenotypes in young male adults. J Clin Periodontol. 1997; 24(1): 65-71. doi: 10.1111/j.1600-051X.1997.tb01186.x. PMID: 9049800.

9) Stetler KJ, Bissada NF. Significance of the width of keratinized gingiva on the periodontal status of teeth with submarginal restorations. J Periodontol. 1987; 58(10): 696-700. doi: 10.1902/jop.1987.58.10.696. PMID: 2444693. 
10) American Academy of Periodontology. Glossary of Periodontal terms. 4th ed. Chicago: American Academy of Periodontology. 2001; 49.

11) Albandar JM, Kingman A. Gingival recession, gingival bleeding, and dental calculus in adults 30 years of age and older in the United States, 1988-1994. J Periodontol. 1999; 70(1): 30-43. doi: 10.1902/jop.1999.70.1.30. PMID: 10052768.

12) Lawrence HP, Hunt RJ, Beck JD. Three-year root caries incidence and risk modeling in older adults in North Carolina. J Public Health Dent. 1995; 55(2): 69-78. doi: 10.1111/j.1752-7325.1995.tb02335.x. PMID: 7643330.

13) Al-Wahadni A, Linden GJ. Dentine hypersensitivity in Jordanian dental attenders. A case control study. J Clin Periodontol. 2002; 29(8): 688-93. doi: 10.1034/j.1600-051X.2002.290804.x. PMID: 12390564.

14) Tarnow DP. Semilunar Coronally Repositioned Flap. J Clin Periodontol. 1986; 13(3): 182-5. doi: 10.1111/j.1600-051X.1986.tb01456.x. PMID: 3457805.

15) Edel A. The use of free connective tissue graft to increase the width of attached gingiva. Oral Surg Oral Med Oral Pathol. 1975; 39(3): 341-6. doi: 10.1016/0030-4220(75)90076-6. PMID: 1054133.

16) Nabers JM. Free gingival grafts. Periodontics. 1966; 4(5): 243-5. PMID: 5223124.

17) Sullivan HC, Atkins JH. Free autogenous gingival grafts. Principles of successful grafting. Periodontics. 1968; 6(3): 121-9. PMID: 5240496.

18) Bernimoulin JP, Luscher B, Muhlemann HR. Coronally repositioned periodontal flap. Clinical evaluation after one year. J Clin Periodontol. 1975; 2(1): 1-13. doi: 10.1111/j.1600-051X.1975.tb01721.x. PMID: 1055724.

19) Cohen DW, Ross SE. The double papillae repositioned flap in periodontal therapy. J Periodontol. 1968; 39(2): 65-70. doi: 10.1902/jop.1968.39.2.65. PMID: 4870433.

20) Grupe HE. Modified technique for sliding flap operation. J Periodontol. 1966; 37(6): 491-5. doi: 10.1902/jop.1966.37.6.491. PMID: 5224017

21) Grupe HE, Warren R. Repair of gingival defects by a sliding flap operation. J Periodontol. 1956; 27(2): 290-5. doi: 10.1902/jop.1956.27.2.92.

22) Patur B. The rotation flap for covering denuded root surfaces: A closed wound technique. J Periodontol. 1977; 48(1): 41-4. doi: 10.1902/jop.1977.48.1.41. PMID: 264540.

23) Pennel BM, Higgason JD, Towner JD, King KO, Fritz BD, Salder JF. Oblique rotated flap. J Periodontol. 1965; 36: 305-9. doi: 10.1902/jop.1965.36.4.305. PMID: 14326697.

24) Restrepo OJ. Coronally repositioned flap: Report of 4 cases. J Periodontol. 1973; 44: 564-7. doi: 10.1902/jop.1973.44.9.564. PMID: 4518844.

25) Miller PD Jr. A classification of marginal tissue recession. Int J Periodont Rest Dent. 1985; 5(2): 8-13. PMID: 3858267.

26) Newman MG, Takei HH, Klokkevold PR, Carranza FA. Carranza’s clinical periodontology. Elsevier. 2012; 11: 598 .

27) Pandit N, Pandit IK, Bali D, Jindal S. Semilunar vestibular technique: A novel procedure for multiple recession coverage (a report of two cases). J Indian Soc Periodontol. 2015; 19(6): 694-7. doi: 10.4103/0972-124X.162204. PMID: 26941524, PMCID: PMC4753718.

28) Landry RG TR, Howley T. Effectiveness of Benzydamine HCL in the treatment of periodontal postsurgical patients. Res Clinic Forums. 1988; 10: 105-18.

29) Haghighat K. Modified Semilunar Coronally Advanced Flap. J Periodontol. 2006; 77(7): 1274-9. doi: 10.1902/jop.2006.050426. PMID: 16805693.

30) Pai BS, Rajan SA, Padma R, Suragimath G, Annaji S, Kamath KV. Modified semilunar coronally advanced flap: A case series. J Indian Soc Periodontol. 2013; 17(1): 124-7. doi: 10.4103/0972-124X.107488. PMID: 23633787, PMCID: PMC3636932. 